\title{
Parametric optimization of microwave reflux extraction of spice oleoresin from white pepper (Piper nigrum)
}

\author{
Olusegun Abayomi Olalere*, Nour Hamid Abdurahman, Oluwaseun Ruth Alara and Omar Abed Habeeb
}

\begin{abstract}
Background: White Piper nigrum is an important commodity crop containing a number of essential bioactive components with nutritional and medicinal properties when sufficiently extracted. Microwave refluxation is therefore a novel technique employed in the extraction of bioactive components from natural products of plant origin. This method doubled as classical and traditional solvent extraction techniques with reduced extraction time, higher selectivity, low solvent consumption, and higher extraction rate.

Methods: The Taguchi $L_{9}$-orthogonal design was employed to determine a combination of extraction factors that jointly optimized the extraction yield. The use of this para metric design was due to its ability to mitigate inherent noise factor with minimal experimental trials.

Results: The optimal extraction condition was attained at 90 min of irradiation time, $300 \mathrm{~W}$ of microwave power, 0.105 $\mathrm{mm}$ of particle size, and $10 \mathrm{ml} / \mathrm{g}$ of molar ratio. Under this condition, the corresponding optimum extraction yield of $4.278(\mathrm{v} / \mathrm{w}) \%$ was obtained. Moreover, the percentage contribution of each extraction factor on the response settings resulted in the decreasing order: irradiation time $>$ molar ratio $>$ power level > particle size. Phytochemical screening was condcuted on the oleoresin extracts and a total number of 26 bioactive compounds were identified. Also, the Fourier Transform Infrared Analysis (FTIR) and the Scanning Eectron Microscopy (SEM) confirmed the presence of seven presence of seven functional groups with an observable structural transformation.

Conclusions: The result of optimum design, phytochemical screening, and structural characterization therefore provided a better understanding on the potential of microwave refluxation in extracting spice oleoresin from white Piper nigrum.
\end{abstract}

Keyword: Characterization, Microwave reflux extraction, Oleoresins, Phytochemical, Taguchi optimization, White pepper

\section{Background}

White Piper nigrum is a commodity crop of Piperaceae family with economical, nutritional and medicinal benefits. It has application in food industries as spices and in pharmaceuticals industries for medicinal purposes (Abdurahman and Olalere, 2016a). It originated from the tropical berries (peppercorns) scientifically known as Piper nigrum. The freshly plucked green berries are allowed to fully mature before being plucked and thereafter soaked in water for up to a week. Once the fresh

\footnotetext{
*Correspondence: olabayor@gmail.com

Faculty of Chemical Engineering and Natural Resources, Universiti Malaysia

Pahang, Lebuhraya Tun Razak 26300 Gambang, Kuantan, Pahang Darul Makmur, Malaysia
}

outer layer deteriorates, it is then scratched until the seeds fall off and dried into a white or creamy seeds as shown in Fig. 1.

The medicinal property of white pepper is due to the presence of an active compound called piperine with a molecular formula of $\mathrm{C}_{17} \mathrm{H}_{19} \mathrm{NO}_{3}$ (Rmili et al. 2014). Vasavirama and Upender (2014) reported that white pepper is made up of $4.6-9 \%$ piperine, $6 \%$ pungent resin, $2.5 \%$ essential oil, and starch. The oleoresin extracts from white pepper possess a characteristics antiinflammatory (Mustapa et al. 2015), antidepressant (Madhu et al. 2009), analgesic (Sabina et al. 2013), antirheumatic (Nahak and Sahu 2011), and adiabatic (Peña-Alvarez et al. 2009) properties. Due to its ability to demobilize 


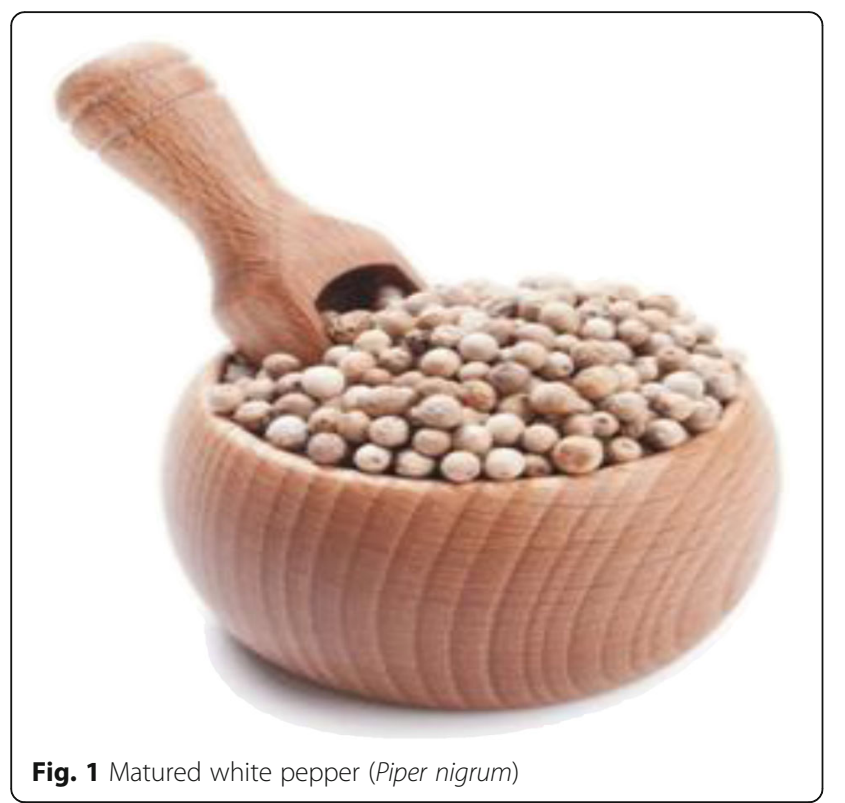

cancer, it is used as bio-enhancer when combined with other drugs in cancer treatment. This is because it increases the bioavailability and efficacy of other drugs (Janakiraman and Manavalan 2008). Raman and V. G. Gaikar (2002) reported that oleoresin extracts does not have pharmacological activity of its own but enhances the assimilation of other drugs.

Many researchers had reported the conventional way of extracting bioactive compounds from white pepper and these include cold percolation (Vittal, 1990) maceration (Singh et al. 2013), soxhlet extraction (Vasavirama and Upender 2014), hydrotropic solubilization (Raman and Gaikar 2002; Mageed 2011), and hydro-distillation (Rmili et al. 2014; Abdurahman and Olalere 2016a). However, several limitations in the used of this method include high solvent consumption, low extraction yield, solvent contamination, higher cost of extraction, and longer extraction time. These setbacks necessitated the use of an improved extraction method involving lower solvent consumption, shorter irradiation time, higher yield, higher selectivity, and environmental friendly. Microwave reflux extraction is a method that provides an efficient way of extracting spice oleoresins from plant matrix (Abdurahman and Olalere 2016b). It works on the principle of ionic conduction and dipole interaction of electric and magnetic field. The ionic conduction offers stiff resistance to the movement of ions which generates an heating effect on the irradiation medium (Abdurahman and Olalere 2016b). An effective extraction is therefore achievable through the use of a multi-directional heating in relation to surface area of the plant matrix. According to Mohan et al. (2013), the reflux microwave extraction is the most appropriate method for extracting samples from plant origin.
Therefore, the aim of this study is to determine a combination of operating conditions for an optimum extraction yield of spice oleoresin from white pepper using taguchi orthogonal design.

\section{Methods}

Material preparation

A standard grade white pepper was purchased from Malaysian Pepper Board (MPB), Sarawak, Malaysia. The initial moisture content was $3-4 \%$ and was then oven dried at $60{ }^{\circ} \mathrm{C}$ for $2 \mathrm{~h}$. The pepper seeds were then crushed and sieved into five different powdered sizes of $0.105,0.154,0.30,0.450$, and $0.90 \mathrm{~mm}$. These were neatly packed inside a sealed nylon for subsequent extraction.

\section{Microwave water-reflux extraction}

Five grams of the sieved sample was mixed with known quantity of distilled water and stirred using a magnetic stirrer. The soaking and stirring operation was performed on the mixture for proper hydration and homogeneity of the sample and solvent. This was then loaded into the microwave extractor and irradiated using the orthogonal experimental design. Moreover, a three-level microwave pulsed heating was employed to reduce superheating effects. The pre-heating process was conducted for $10 \mathrm{~min}$ at $100{ }^{\circ} \mathrm{C}$, irradiated based on the experimental design and cooled to $30{ }^{\circ} \mathrm{C}$ for $5 \mathrm{~min}$. The introduction of pulsed heating (i.e., pre-heatingirradiation-cooling modes) was to reduce the variation imposed upon the system from temperature fluctuation. The sample was thereafter unloaded from the extractor and centrifuged at $5000 \mathrm{rpm}$ for $15 \mathrm{~min}$ using the refrigerated centrifuged (5810R eppendorf model). The extract was concentrated using rotary evaporator (BUCHI, R-200 model, Germany) and the extraction yield was estimated from the final extract concentrate using Equation (1). The oleoresin extracts concentrate was then stored at $4{ }^{\circ} \mathrm{C}$ for subsequent GC-MS analysis and chemical characterization.

$$
\begin{aligned}
& \text { Extraction yield } \mathrm{v} / \mathrm{w}(\%) \\
& \qquad \frac{\text { Amount of oleoresine extracted }(\mathrm{ml})}{\text { Weight of dried sample used }(\mathrm{g})} \times 100 \%
\end{aligned}
$$

\section{GC-MS analysis}

The extract was analyzed using GC-MS (Agilent 5973model, USA) equipped with C-18 column (30 mm tubular column diameter, $0.25-\mathrm{mm}$ internal diameter and $0.25-\mu \mathrm{m}$ film thickness). The column initial oven hold was operated at $50{ }^{\circ} \mathrm{C}$ for $5 \mathrm{~min}$ and then allowed to rise to $250{ }^{\circ} \mathrm{C}$ at $3{ }^{\circ} \mathrm{C}$ per minute with an additional $300{ }^{\circ} \mathrm{C}$ 
for 5 min. A small portion of clear golden-colored supernatant solution was filtered using the $0.45 \mu \mathrm{m}$ PTFE micro filter and diluted with analytical grade acetone to 1:10. One microliter of the diluted solution was then injected into the gas chromatography column at $280{ }^{\circ} \mathrm{C}$ at a helium gas velocity of $1 \mathrm{ml} / \mathrm{min}$. The peak area fragmentation fingerprints for different components were matched with the NIST05a.Library database.

\section{Characterization of residue and oleoresin extract}

Fourier transform infrared spectroscopy (FTIR) was carried out to determine the bonding structures and functional group characteristics of the liquid extracts. This was performed using a Thermo-Nicolet 6700-IR spectrometer equipped with a DTGS detector and $\mathrm{KBr}$ Beam-splitter. The analysis was executed using the conventional $\mathrm{KBr}$ standard procedure with wave number ranging from $4000-500 \mathrm{~cm}^{-1}$. Under this study the spectral from the oleoresin extract with characteristics bond and group frequencies were compared with the table of expected absorption bands of different functional groups (Chupin et al. 2015). SEM-images of dried residue were analyzed before and after extraction, to determine the morphological transformation occassioned by the microwave radiation.

\section{Results and discussion}

\section{Effect of irradiation time}

In Fig. 2, the effects of irradiation time on the extraction yield was investigated at constant temperature $\left(70{ }^{\circ} \mathrm{C}\right)$, feed particle size $(0.105 \mathrm{~mm})$, microwave power $(200 \mathrm{~W})$, and molar ratio $(6 \mathrm{ml} / \mathrm{g})$. The results obtained show a sharp increase in the extraction yield as the irradiation time increased progressively from 30 to $60 \mathrm{~min}$. This suggest an initial direct proportionality between the irradiation time and the extraction yield as reported by Rouatbi et al. (2007). The yield nearly constant out from 60 to $90 \mathrm{~min}$ of the extraction time after which the extraction yield experienced a decline.

\section{Effect of microwave power}

Figure 3 shows the effect of microwave power on the extraction yield at constant irradiation time (30 min), temperature $\left(70{ }^{\circ} \mathrm{C}\right)$, feed particle size $(0.105 \mathrm{~mm})$, and molar ratio $(6 \mathrm{ml} / \mathrm{g})$. The microwave power was varied at 200, 250,300,350, and $400 \mathrm{~W}$. The result revealed that the extraction yield increased steadily as the microwave power increased from 200 to $250 \mathrm{~W}$ and later became constant before declining finally at $300 \mathrm{~W}$. The initial rise in the yield could be attributed to the breakup of the parenchyma cell wall which results in the exudation of bioactive compounds from the cellulosic cell wall. This suggests that an increase in microwave power induces an accelerated effect on the ionic conduction and dipole rotation (Khajeh and Ghanbari2011).

\section{Effect of feed particle size}

Figure 4 shows the effects of particle size on the extraction yield at constant irradiation time (30 mins), temperature $\left(70{ }^{\circ} \mathrm{C}\right)$, molar ratio $(6 \mathrm{ml} / \mathrm{g})$ and microwave power $(200 \mathrm{~W})$. The result shows an higher yield with a particle size of $0.105 \mathrm{~mm}$. This indicated that a smaller particle size provided a larger surface area for solvent penetration and hence increase the extraction yield (Huie 2002).

\section{Effect of molar ratio}

Figure 5 shows the effects of molar ratio on the yield at constant irradiation size, microwave power and particle

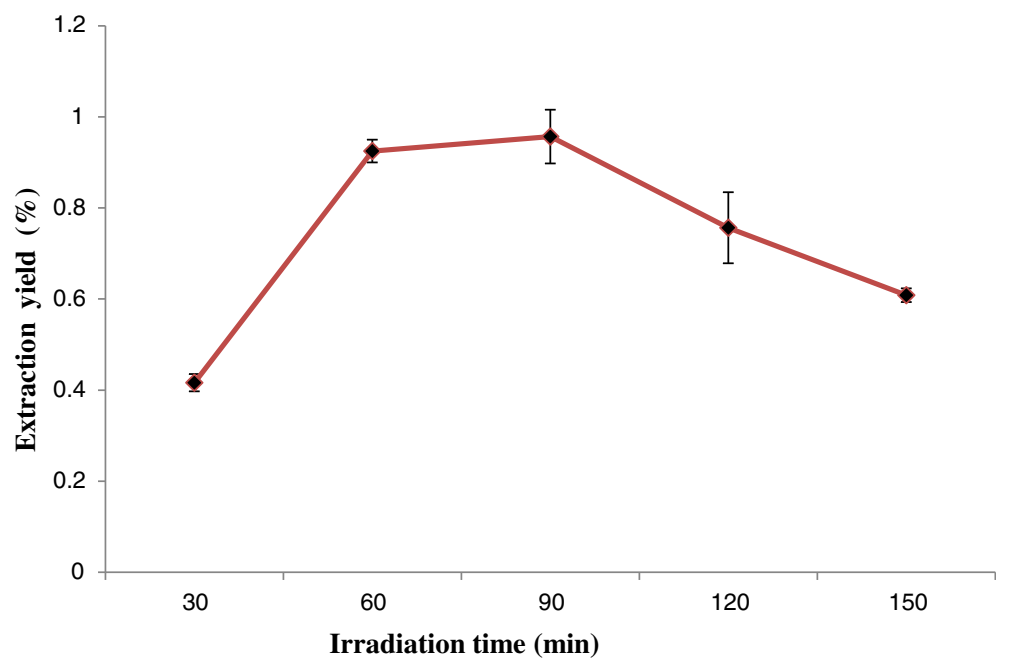

Fig. 2 Effect of irradiation time 


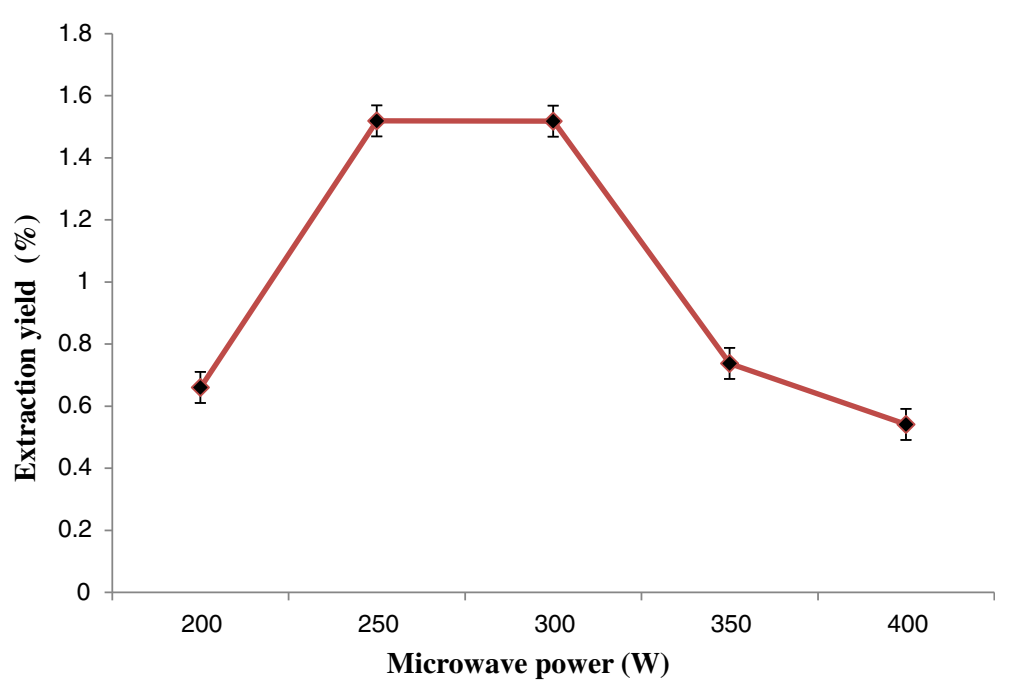

Fig. 3 Effect of microwave power

size. The yield increased progressively up to $8 \mathrm{ml} / \mathrm{g}$ and thereafter became constant from $8 \mathrm{ml} / \mathrm{g}$ to $10 \mathrm{ml} / \mathrm{g}$. However, there was a decline after $10 \mathrm{ml} / \mathrm{g}$ which shows depletion of extractable oleoresin in the white pepper matrix.

\section{Determination of factor range}

Three level operating conditions were selected from the single factor experiment for each extraction factors :irradiation time (A), microwave power level (B), feed particle size $(C)$, and molar ratio (D). The selection were based on the 'largest donating rule' which was used in the designing of the $\mathrm{L}_{9}$-orthogonal array $(\mathrm{Du}$ et al.
2013); Mandal et al.2008). The summary of the selected three-levels are presented in Table 1.

\section{Taguchi Optimization}

Taguchi orthogonal optimization was employed to determine the optimum condition for the extraction of spice oleoresin from white pepper. The combination of extraction parameters for an optimum yield were designed and analyzed using Minitab $17^{\circ}$ software (Pan 2014). This was achieved using a 3-level $\mathrm{L}_{9}$-orthogonal design with the 'larger-the-better' transfer function as illustrated in Equation (2).This involves a two-step optimization approach which concentrates more on providing tolerance

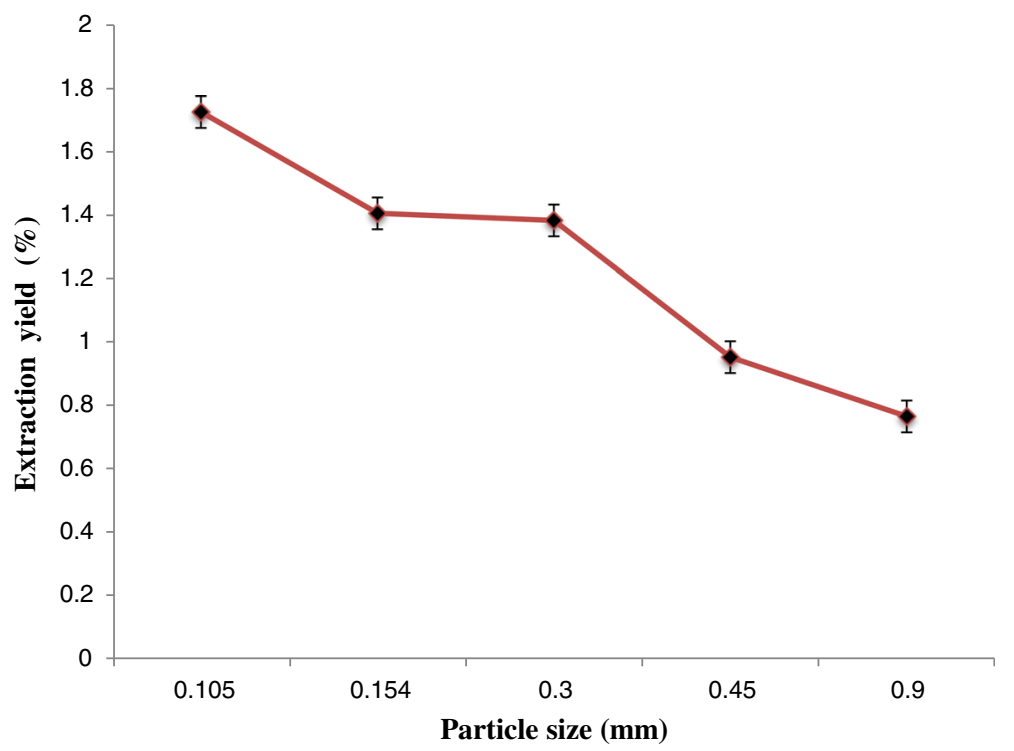

Fig. 4 Effects of feed particle size 


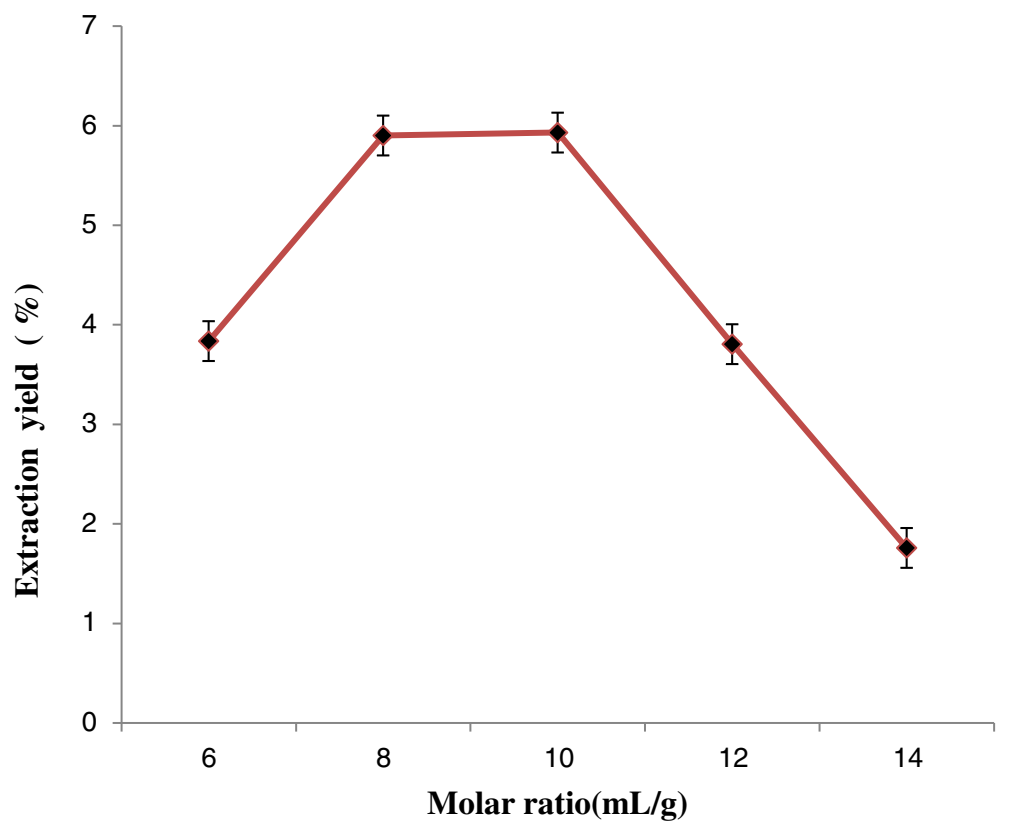

Fig. 5 Effects of feed particle size

level and minimizing response variation in the process of searching for an optimal condition.

$$
S N R=-10 * \log 10\left\{\sum\left(\frac{1}{y}\right)^{2} / n\right\}
$$

where $y$ is the response value, and $n$ is the number of observation.

From Table 2, the optimal extraction condition was attained at $90 \mathrm{~min}$ of irradiation time, $300 \mathrm{~W}$ of microwave power, $0.105 \mathrm{~mm}$ of particle size, and $10 \mathrm{ml} / \mathrm{g}$ of molar ratio with an optimal yield of $4.28(\mathrm{v} / \mathrm{w}) \%$. A triplicate confirmatory tests were then carried out under the optimal operating condition, to validate the optimal response. The results from the triplicate confirmatory runs were as follows: $4.30,4.25$, and $4.28(\mathrm{v} / \mathrm{w}) \%$. Relative standard deviation (R.S.D) was then estimated to quantify the error in the optimal yield. A relative standard deviation of $0.55 \%$ is an indication of better prediction in the experimental design. The $\mathrm{SN}$-ratio characteristic is usually positive, however, a negative $\mathrm{SN}$-ratio indicate that the noise value is greater than the signal value (Pan

Table 1 Extraction factors and levels

\begin{tabular}{llllll}
\hline Control factors & Symbols & Units & $\begin{array}{l}\text { Level 1 } \\
(-1)\end{array}$ & $\begin{array}{l}\text { Level 2 } \\
(0)\end{array}$ & $\begin{array}{l}\text { Level 3 } \\
(+1)\end{array}$ \\
\hline Irradiation time & $\mathrm{A}$ & $\mathrm{min}$ & 30 & 60 & 90 \\
Microwave power & $\mathrm{B}$ & $\mathrm{W}$ & 250 & 300 & 350 \\
Feed particle size & $\mathrm{C}$ & $\mathrm{mm}$ & 0.105 & 0.154 & 0.300 \\
Molar ratio & $\mathrm{D}$ & $\mathrm{ml} / \mathrm{g}$ & 6 & 8 & 10 \\
\hline
\end{tabular}

2014). Therefore, the SN-ratio for white water-reflux was found to be 12.62 at a maximum yield of $4.28 \%$. This clearly indicated that the experimental condition at larger-the-better $\mathrm{SN}$-ratio can only be obtained with the maximum response. Hence, the optimum level is the one with the highest SN-ratio. This is the basis for deciding the optimum conditions for each independent extraction factor as reported by Mandal et al. (2008).

\section{Average mean effects}

The optimum response means was computed at different operating level for each of the extraction factor as reported by Abbass et al. (2016). (2016). The results show that the irradiation time has the highest average mean effects on the oleoresin yield. This suggests that irradiation time has the highest contribution to the microwave refluxation of spice oleoresins from white pepper. The percentage contribution of each extraction factor was estimated as $29.73,26.06,24.41$, and $19.79 \%$ for irradiation time, molar ratio, microwave power, and particle size, respectively (Table 3 ).

\section{Chemical composition of the oleoresin extracts}

The GC-MS analysis of the spice oleoresin extracted from white pepper is presented in Table 4. The extracts showed a total of 26 components with piperine (54.67\%) as the major component, followed by caryophyllene $(11.21 \%)$ at a retention time (RT) of 48.994 and 35.216 min, respectively. The results indicated that the extracted oleoresin is made up of $60.39 \%$ alkaloids, $19.69 \%$ monoterpenes and $22.36 \%$ sesquiterpenes. This shows 
Table $2 L_{9}(3 \wedge 4)$ experimental matrix, response and SN-ratio

\begin{tabular}{|c|c|c|c|c|c|c|}
\hline \multirow[t]{3}{*}{ Exp. no. } & \multicolumn{4}{|c|}{ Control factors } & \multirow{3}{*}{$\begin{array}{l}\text { Response } \\
\text { Extraction } \\
\text { yield }(v / w) \%\end{array}$} & \multirow{3}{*}{$\begin{array}{l}\text { Estimated } \\
\text { SN-ratio }\end{array}$} \\
\hline & \multirow{2}{*}{$\begin{array}{l}\text { Irradiation } \\
\text { time (min) } \\
\text { A:A }\end{array}$} & \multirow{2}{*}{$\begin{array}{l}\text { Microwave } \\
\text { power(W) } \\
\text { B:B }\end{array}$} & \multirow{2}{*}{$\begin{array}{l}\text { Particle } \\
\text { size }(\mathrm{mm}) \\
\mathrm{C}: \mathrm{C}\end{array}$} & \multirow{2}{*}{$\begin{array}{l}\text { Molar } \\
\text { ratio(ml/g) } \\
\text { D:D }\end{array}$} & & \\
\hline & & & & & & \\
\hline 1 & -1 & -1 & -1 & -1 & $0.49 \pm 0.02$ & -6.13 \\
\hline 2 & -1 & 0 & 0 & 0 & $0.62 \pm 0.01$ & -4.21 \\
\hline 3 & -1 & +1 & +1 & +1 & $1.83 \pm 0.04$ & 5.23 \\
\hline 4 & 0 & -1 & 0 & +1 & $0.17 \pm 0.07$ & -15.60 \\
\hline 5 & 0 & 0 & +1 & -1 & $0.21 \pm 0.08$ & -13.39 \\
\hline 6 & 0 & +1 & -1 & 0 & $0.92 \pm 0.01$ & -0.69 \\
\hline 7 & +1 & -1 & +1 & 0 & $0.26 \pm 0.05$ & -11.77 \\
\hline 8 & +1 & 0 & -1 & +1 & $4.28 \pm 0.04$ & 12.62 \\
\hline 9 & +1 & +1 & 0 & -1 & $1.87 \pm 0.32$ & 5.44 \\
\hline
\end{tabular}

that the alkaloid has the larger fraction followed by the hydrocarbons (i.e., monoterpenes and sesquiterpenes). However guineensine, 1-cinnamoyl piperidine, piperettine, $\alpha$-selinene, and $\alpha$-cubebene were found to be in trace amount as reported by Singh et al. (2013).

\section{Structural analysis}

Table 5 and Fig. 6 show the predicted reference wave number and that obtained from the experimental infrared absorption, respectively. A stronger intensity was observed for oxygenated $\mathrm{C}=\mathrm{O}$ and $\mathrm{C}=\mathrm{O}$ stretching with observed wave numbers 1737.5 and $1704.0 \mathrm{~cm}^{-1}$, respectively indicating a high level of ketonic group. A weak peak at $1444.2 \mathrm{~cm}^{-1}$ corresponds to $\mathrm{C}-\mathrm{H}_{2}$ bending in alkane whereas the broad spectrum of $3430.2 \mathrm{~cm}^{-1}$ is a representation $\mathrm{O}-\mathrm{H}$ alcohol derivative. The bond vibration in $\mathrm{C}-\mathrm{O}$ and $=\mathrm{C}-\mathrm{O}-\mathrm{C}$ asymmetrical stretching have gave an observed wave numbers of 1240.8 and $1256.0 \mathrm{~cm}^{-1}$, respectively. Also, a weak peak at $1091.4 \mathrm{~cm}^{-1}$ is associated with the presence of C-N. This result shows that the microwave reflux extraction is a highly selective and appropriate method for the extraction of spice oleoresin from white pepper without the degradation of bioactive compounds as confirmed by Saha et al. (2013).

Figure $7 \mathrm{a}$ and $\mathrm{b}$ clearly elucidated the morphological transformation of the untreated and microwave radiated

Table 3 Main effect of response means

\begin{tabular}{lllll}
\hline & $\begin{array}{l}\text { Irradiation time } \\
(\mathrm{min})\end{array}$ & $\begin{array}{l}\text { Microwave } \\
\text { power(W) }\end{array}$ & $\begin{array}{l}\text { Particle } \\
\text { size }(\mathrm{mm})\end{array}$ & $\begin{array}{l}\text { Molar } \\
\text { ratio(ml/g) }\end{array}$ \\
\hline Level 1 & 0.9790 & 0.3060 & 1.8980 & 0.8593 \\
Level 2 & 0.4347 & 1.7020 & 0.8840 & 0.5993 \\
Level 3 & 2.1347 & 1.5403 & 0.7663 & 2.0897 \\
\% Contribution & 29.73 & 24.41 & 19.79 & 26.06 \\
Optimality Ranking & 1st & 3rd & 4th & 2nd \\
\hline
\end{tabular}

Table 4 GC-MS analysis of various components inside the oleoresins

\begin{tabular}{|c|c|c|c|c|}
\hline No & Component & Formula & $\begin{array}{l}\text { RT } \\
\text { (min) }\end{array}$ & $\begin{array}{l}\text { Composition } \\
\text { ( } \% \text { mass) }\end{array}$ \\
\hline 1 & a- Thujene & $\mathrm{C}_{10} \mathrm{H}_{16}$ & 17.288 & 0.24 \\
\hline 2 & a- Pinene & $\mathrm{C}_{10} \mathrm{H}_{16}$ & 18.855 & 2.25 \\
\hline 3 & Sabinene & $\mathrm{C}_{10} \mathrm{H}_{16}$ & 19.170 & 8.37 \\
\hline 4 & Limonene & $\mathrm{C}_{10} \mathrm{H}_{16}$ & 19.384 & 6.32 \\
\hline 5 & Isothujol & $\mathrm{C}_{10} \mathrm{H}_{18} \mathrm{O}$ & 19.406 & 0.86 \\
\hline 6 & Linalool & $\mathrm{C}_{10} \mathrm{H}_{18} \mathrm{O}$ & 21.986 & 1.37 \\
\hline 7 & Terpinen-4-ol & $\mathrm{C}_{10} \mathrm{H}_{18} \mathrm{O}$ & 27.365 & 1.12 \\
\hline 8 & a-Terpineol & $\mathrm{C}_{10} \mathrm{H}_{18} \mathrm{O}$ & 27.891 & 0.95 \\
\hline 9 & a-Cubebene & $\mathrm{C}_{15} \mathrm{H}_{24}$ & 30.641 & 0.04 \\
\hline 10 & $\beta$-Elemene & $\mathrm{C}_{15} \mathrm{H}_{24}$ & 34.452 & 0.52 \\
\hline 11 & Copaene & $\mathrm{C}_{15} \mathrm{H}_{24}$ & 34.369 & 0.43 \\
\hline 12 & $\gamma$ - Elemene & $\mathrm{C}_{15} \mathrm{H}_{24}$ & 34.884 & 0.87 \\
\hline 13 & Caryophyllene & $\mathrm{C}_{15} \mathrm{H}_{24}$ & 35.216 & 11.21 \\
\hline 14 & Y-Muurolene & $\mathrm{C}_{15} \mathrm{H}_{24}$ & 37.328 & 1.10 \\
\hline 15 & a-Selinene & $\mathrm{C}_{15} \mathrm{H}_{24}$ & 39.253 & 0.02 \\
\hline 16 & $\beta$-Bisabolene & $\mathrm{C}_{15} \mathrm{H}_{24}$ & 40.012 & 3.10 \\
\hline 17 & $\beta$-Sitosterin & $\mathrm{C}_{29} \mathrm{H}_{50} \mathrm{O}$ & 41.754 & 2.43 \\
\hline 18 & 1-Cinnamoyl piperidine & $\mathrm{C}_{15} \mathrm{H}_{17} \mathrm{NO}_{3}$ & 42.726 & 0.03 \\
\hline 19 & Piperlonguminine & $\mathrm{C}_{16} \mathrm{H}_{19} \mathrm{NO}_{3}$ & 45.607 & 0.14 \\
\hline 20 & Piperine & $\mathrm{C}_{17} \mathrm{H}_{19} \mathrm{NO}_{3}$ & 48.994 & 54.67 \\
\hline 21 & Piperanine & $\mathrm{C}_{17} \mathrm{H}_{21} \mathrm{NO}_{3}$ & 49.535 & 0.45 \\
\hline 22 & Piperamide & $\mathrm{C}_{17} \mathrm{H}_{28} \mathrm{~N}_{4} \mathrm{O}$ & 49.791 & 0.98 \\
\hline 23 & Piperolein & $\mathrm{C}_{19} \mathrm{H}_{25} \mathrm{NO}_{3}$ & 50.139 & 0.22 \\
\hline 24 & Piperettine & $\mathrm{C}_{19} \mathrm{H}_{21} \mathrm{NO}_{3}$ & 51.027 & 0.06 \\
\hline 25 & Pipercide & $\mathrm{C}_{22} \mathrm{H}_{29} \mathrm{NO}_{3}$ & 51.059 & 0.21 \\
\hline 26 & Guineensine & $\mathrm{C}_{24} \mathrm{H}_{33} \mathrm{NO}_{3}$ & 51.460 & 0.01 \\
\hline
\end{tabular}

white pepper powders using scanning electron microscopy analyzer. Prior to the microwave extraction, elongated parenchyma and stone cells of the pepper matrix was tightly packed. These cell walls became expanded and thereafter ruptured on exposure to the microwave

Table 5 Functional groups from the FTIR-analysis

\begin{tabular}{llcl}
\hline Functional groups & \multicolumn{2}{l}{ Wavenumber $\left(\mathrm{cm}^{-1}\right)$} & $\begin{array}{l}\text { Peak } \\
\text { strength }\end{array}$ \\
\cline { 2 - 3 } & *Predicted & Observed & \\
\hline $\mathrm{C}-\mathrm{H}_{2}$ bending & 1450 & 1444.2 & Weak \\
$\mathrm{C}=\mathrm{O}$ ketone & 1738 & 1737.5 & Strong \\
$\mathrm{C}-\mathrm{O}$ & 1245 & 1240.8 & Strong \\
$\mathrm{C}-\mathrm{N}$ & 1092 & 1091.4 & Medium \\
$\mathrm{C}=$ O stretching & 1700 & 1704.0 & Weak \\
=C-O-C asymmetrical stretching & 1254 & 1256.0 & Strong \\
O-H alcohol-strong and broad & 3429 & 3430.2 & Strong \\
\hline
\end{tabular}

Source: Chupin et al. (2015); Saha et.al (2013) 


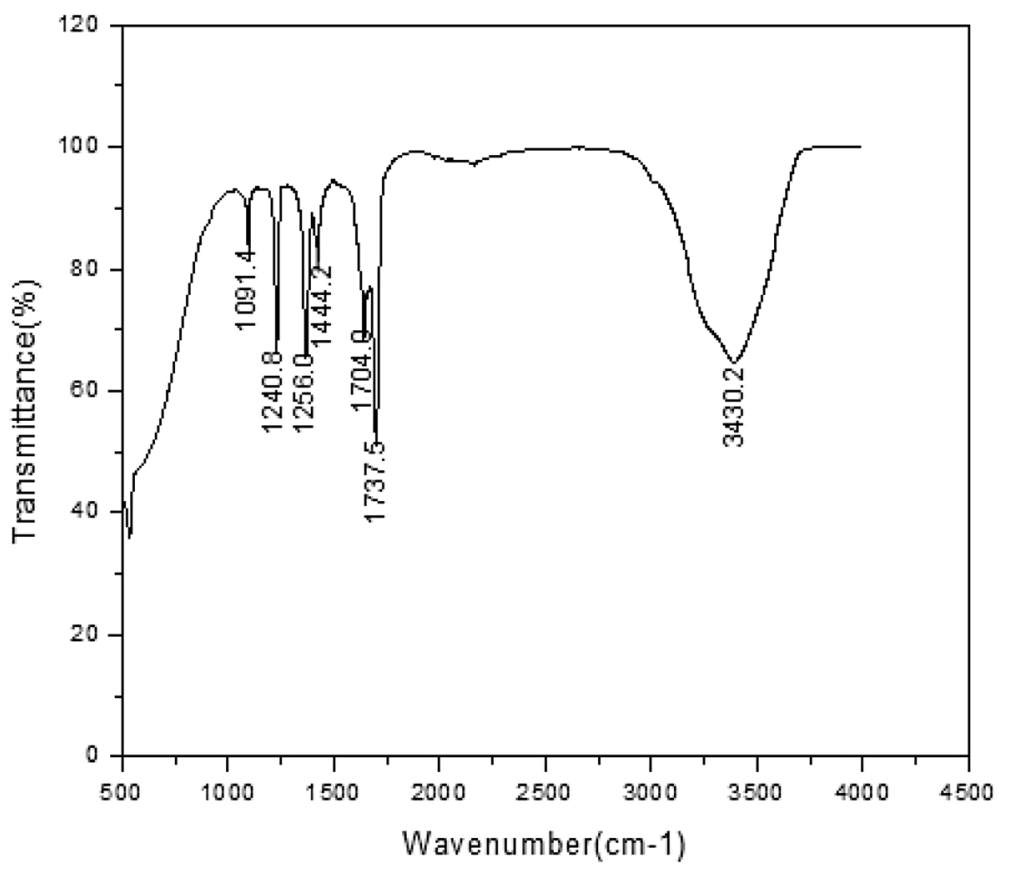

Fig. 6 FTIR-spectra of liquid extract

radiation. This resulted in a subsequent release of bioactive components from the cellulose cell wall.

\section{Conclusions}

The optimum operating condition for the extraction of spice oleoresin from white pepper was attained at 90 min of irradiation time, $300 \mathrm{~W}$ of microwave power, $0.105 \mathrm{~mm}$ of particle size, and $10 \mathrm{ml} / \mathrm{g}$ of molar ratio.
Under this condition, the optimal extraction yield of $4.278(\mathrm{v} / \mathrm{w}) \%$ was obtained. The decreasing order of significance of the four extraction factors was given as irradiation time $>$ molar ratio $>$ power level $>$ particle size. This study therefore suggests that for an optimized extraction of spice oleoresin from white pepper, the irradiation time must be properly monitored being the most significant factor in the extraction process. The

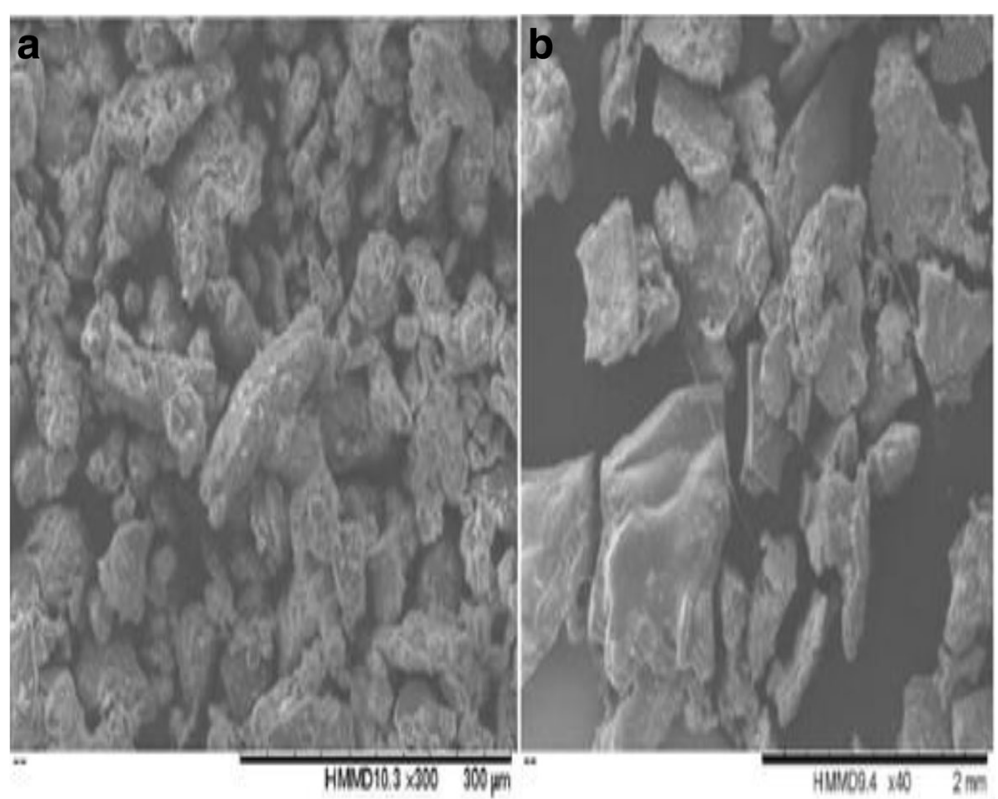

Fig. 7 a SEM-image for pre-extraction (b) SEM-image for post-extraction 
phytochemical screening and FTIR analyses on the extracts confirmed the presence of a total of 26 bioactive chemical compounds and seven functional groups. The SEM images further elucidated the structural transformation of the white pepper matrix as a result of microwave heating. The results established the potential of microwave reflux extraction as an efficient and productive extraction technique.

\section{Acknowledgements}

The authors wish to acknowledge the financial support and sponsorship from the Doctoral Scholarship Scheme of the Malay sian Ministry of Education (MOE), and the PGRS-160320 research grant from Universiti Malaysia Pahang (UMP), Malaysia.

\section{Authors' contributions}

OOA conducted the experiments and developed the robust experimental design. AHN supervised the experimental and provided useful insight into the project. AOR conducted the GC-Ms analysis and typesetting of the manuscripts. OAH helped in the statistical analysis of the experimental data. All authors read and approved the final manuscript.

\section{Competing interests}

The authors declare that they have no competing interests.

\section{Publisher's Note}

Springer Nature remains neutral with regard to jurisdictional claims in published maps and institutional affiliations.

Received: 16 October 2016 Accepted: 8 April 2017

Published online: 27 April 2017

\section{References}

Abbass MK, Hussein SK, Khudhair AA. Optimization of Mechanical Properties of Friction Stir Spot Welded Joints for Dissimilar Aluminum Alloys (AA2024-T3 and AA 5754-H114). Arab J Sci Eng. 2016. doi:10.1007/s13369-016-2172-9.

Abdurahman $\mathrm{NH}$, Olalere OA. A comparative review of conventional and microwave assisted extraction in capsaicin isolation from chili pepper. Aust J Bas Appl Sci. 2016a;10(6):263-75.

Abdurahman NH, Olalere OA. Taguchi-based based optimization technique in reflux microwave extraction of piperine from black pepper (Piper nigrum). Aust J Bas Appl Sci. 2016b;10(5):293-9.

Chupin L, Maunu SL, Reynaud S, Pizzi A, Charrier B, Bouhtoury FC-E. Microwave assisted extraction of maritime pine (Pinus pinaster) bark: Impact of particle size and characterization. Ind Crops Prod. 2015;65(0):142-9. http://dx.doi.org/ 10.1016/j.indcrop.2014.11.052.

Du HY, Shen ZJ, Li Y. Microwave-assisted extraction of capsaicin from chili pepper powder. Adv Mater Res. 2013;634-638:1591-4. doi:10.4028/www. scientific.net/AMR.634-638.1591.

Huie CW. A review of modern sample-preparation techniques for the extraction and analysis of medicinal plants. Anal Bioanal Chem. 2002;373(1-2):23-30 doi:10.1007/s00216-002-1265-3.

Janakiraman K, Manavalan R. Studies on effect of piperine on oral bioavailability of ampicillin and norfloxacin. Afr J Tradit Complement Altern Med. 2008;5(3): 257-62. doi:10.4314/ajtcam.v5i3.31281.

Khajeh M, Ghanbari A. Application of factorial design and Box-Behnken matrix in the optimisation of a microwave-assisted extraction of essential oils from Salvia mirzayanii. Nat Prod Res. 2011:25(18):1766-70. doi:10.1080/14786419. 2010.534095

Madhu MN, Ramalingam R, Swetha D. Extraction, identification, formulation and evaluation of piperine in alginate beads. Int J Phar Pharm Sci. 2009;1(2):156-61.

Mageed MA, Mansour AF, El Massry KF, Ramadan MM, Shaheen MS. The effect of microwaves on essential oils of white and black pepper (Piper nigrum L.) and their antioxidant activities. J Essent Oil Bear Plants. 2011;14(2):214-23. doi: 10. 1080/0972060X2011.10643924.

Mandal V, Mohan Y, Hemalatha S. Microwave assisted extraction of curcumin by sample-solvent dual heating mechanism using Taguchi L9 orthogonal design. J Pharm Biomed Anal. 2008;46(2):322-7. doi:10.1016/j.jpba.2007.10.020.
Mohan M, Khanam S, Shivananda BG. Optimization of microwave assisted extraction of andrographolide from andrographis paniculata and its comparison with refluxation extraction method. J Pharmacog Phytochem. 2013:2(1):342-8.

Mustapa AN, Martin Á, Mato RB, Cocero MJ. Extraction of phytocompounds from the medicinal plant Clinacanthus nutans Lindau by microwave-assisted extraction and supercritical carbon dioxide extraction. Ind Crops Prod. 2015;74:83-94. doi:10.1016/j.indcrop.2015.04.035.

Nahak G, Sahu RK. Phytochemical evaluation and antioxidant activity of piper cubeba and piper nigrum. J Appl Pharm Sci. 2011;1(8):153-7.

Pan J. Minitab Tutorials for Design and Analysis of Experiments. 2014:1-32. http://www.calpoly.edu/ pan/teaching/MinitabDOETutorial.pdf Accessed 21 Sept 2017

Peña-Alvarez A, Ramírez-Maya E, Alvarado-Suárez LA. Analysis of capsaicin and dihydrocapsaicin in peppers and pepper sauces by solid phase microextraction-gas chromatography-mass spectrometry. J Chromatogr A. 2009;1216(14):2843-7. doi:10.1016/j.chroma.2008.10.053.

Raman G, Gaikar VG. Extraction of piperine from Piper nigrum (black pepper) by hydrotropic solubilization. Ind Eng Chem Res. 2002;41:2966-76. doi:10.1021/ ie0107845.

Raman G, Gaikar VG. Micowave-Assisted Extraction of Piperine from Piper nigrumr. Ind Eng Chem Res. 2002:41(10):2521-28.

Rmili R, Ramdani M, Ghazi Z, Saidi N, El Mahi B. Composition comparison of essential oils extracted by hydrodistillation and microwave-assisted hydrodistillation from Piper nigrum L. J Mater Environ Sci. 2014;5(5):1360-7. doi:10.1080/0972060X.2010.10643823.

Rouatbi M, Duquenoy A, Giampaoli P. Extraction of the essential oil of thyme and black pepper by superheated steam. J Food Eng. 2007;78(2):708-14. doi:10.1016/j.jfoodeng.2005.11.010

Sabina EP, Nasreen A, Vedi M, Rasool M. Analgesic, antipyretic and ulcerogenic effects of piperine: an active ingredient of pepper. J Pharm Sci Res. 2013;5(10):203-6.

Saha KC, Seal HP, Noor MA. Isolation and characterization of piperine from the fruits of black pepper (Piper nigrum). J Bangladesh Agril Univ. 2013;11(1):11-6.

Singh S, Kapoor IPS, Singh G, Schuff C, Lampasona MP, Catalan CAN. Chemistry, antioxidant and antimicrobial potentials of white pepper (Piper nigrum L.) essential oil and oleoresins. Proc Natl Acad Sci India Sect B - Biol Sci. 2013;83(3):357-66. doi:10.1007/s40011-012-0148-4.

Vasavirama K, Upender M. Piperine: a valuable alkaloid from piper species. Int J Pharm Pharm Sci. 2014;6(4):34-8.

Vittal RS. A modified extraction and estimation method of oleoresin and piperine in black pepper (Piper nigrum L.) berrie. Cent Plant Crop Res Institute,Regional Stn. 1990:3:56-66.

\section{Submit your manuscript to a SpringerOpen ${ }^{\circ}$ journal and benefit from:}

- Convenient online submission

- Rigorous peer review

- Immediate publication on acceptance

- Open access: articles freely available online

- High visibility within the field

- Retaining the copyright to your article

Submit your next manuscript at $>$ springeropen.com 